\title{
REGIONAL CENTRE DEVELOPMENT MANAGEMENT FACTORS: CASE STUDY OF LIEPAJA
}

\author{
Andris Ozols ${ }^{1}$, Valdis Avotins ${ }^{2}$ \\ ${ }^{1}$ Riga Technical University, Latvia; ${ }^{2}$ Riga Photonics Centre, Latvia \\ andris.demo@gmail.com
}

\begin{abstract}
The number of special economic zones (SEZs) and industrial parks worldwide is constantly increasing, and the Industry 4.0 demands extremely high agility level and more effective approaches to maintain competitiveness of SEZ. The paper deals with questions related to the strategic management of SEZ as the regional development promoter. It evaluates the main factors affecting SEZ's economic development, analyses the opportunities for specialization areas in the context of global challenges, considers the potential for growth of talent pool in Liepaja, with a special emphasis on the importance of education. The study has been conducted using desk research, analysis of global trends and good practices, and expert interviews. It concludes that new industrial parks are characterized by academic and technological development, close cooperation between academic, business, and public administration, where the university no longer fulfils only a simple educational function but is an active source of change, innovation driver and tester, and a magnet for creating and attracting talents. In the face of today's challenges, formal model of SEZ gives just a new formal status without tangible added value. Key factors affecting SEZ activities are the management of SEZ with clearly defined priorities, political will and initiative, the availability of a talented highly skilled and motivated workforce, meaningful use of fiscal incentives and cooperation with the university. The economic situation of Liepaja is characterized by low wages, low innovation capacity and technology absorption capacity, low productivity, and low-skilled labour. The SEZ should be able to adapt the strategy to changing global trade patterns: strategic reorientation, mobilizing dynamic businesses, moving towards technological growth, attracting talents, developing well-defined high value-added priority sectors.
\end{abstract}

Keywords: industrial parks, SEZ, talent, Industry 4.0.

\section{Introduction}

Almost two decades have passed since the World Bank's (WB) evaluations of Latvia's National Innovation System performance and 30 years since the Special Economic Zone were created in Liepaja and Rezekne, two major regional development centres [1]. The WB report clearly outlined Latvia's lagging behind Europe in high-tech manufacturing, export, productivity, innovation, and value added, confirmed by the European Innovation Index. The pace is slow - this term can also be extended to the speed of innovation in Latvia. The EU Innovation Report 2020 shows that compared to 2012, Latvia is among 4 countries (Lithuania, Portugal, Greece) with the highest growth seen during this period. However, compared to the EU average, Latvia and Lithuania show below average, while Estonia ranks among the strong innovators. Given that Lithuania is a major competitor, Lithuania has grown more rapidly during this period - by 27.8 percentage points compared to Latvia's 23.3 percentage points [2].

Latvia as an EU member state has received solid structural fund allocations in pre-accession and two following planning periods (e.g., 2007-2013 and 2014-2020). Operation of four free zones was expected to become an economic breakthrough instrument for recovery and rapid growth of national economy. Instead of this we see even worse trend, where, besides five weaknesses, two more have arisen - growing regional disparities and emigration of domestic talent.

This paper is aimed to try to analyse why the SEZ instrument has not brought planned development in a region, while we may find similar winning cases around Europe and what factors we need to reassess in innovation policy redesign to reshape existing continuous divergence from other Baltic neighbours to catching up and overtaking actions. What determines that the SEZs can initiate and achieve the desired structural reforms in the long term? The strategic development of the Liepaja SEZ ("LSEZ") has been taking place since its inception in 1997, but the disparities compared to Riga remain and are even increasing.

This raises the main challenges - how should the SEZ management be improved and what are the factors that have an impact on the development of the SEZ? Are labour and infrastructure availability the most important aspects in the regional growth? The aim of this paper is to find out what the most important factors are that affect the success of the SEZ. 


\section{Research methods}

The methods used include desk research, global trend analysis, case studies of proved champions, and expert interviews. As a result, the 5 main factors affecting SEZ operation are identified. The authors address global challenges (in particular, the "Covid" pandemic and Industry 4.0), gather the main lessons from successful and ineffective SEZ and Industrial Park examples, define priority sectors and segments, as well as define key factors determining LSEZ operation, and activities that would most effectively increase the readiness for the absorption of external technologies.

Foremost - how to define scientific parks and whether there is a common definition of them? Literature sources show that there are several analogues used for these concepts in different countries, and a strict definition does not exist. For example, H. Lofsten and P. Lindelof point out that the terms "technology park", "business park", "technological centre", etc. have a similar meaning [3]. The terminology used in different countries is very inconsistent and the most used terms - special economic or export processing zones, industrial parks, technological parks, science parks, technopoles - are used inappropriately. The report chooses to use the term "industrial park" as a general term covering all types - including SEZ. The SEZ is also characterised by a variety of names (including free zones, export processing zones and industrial parks) and has many variations. However, governments also use other zoning-related concepts (e.g., science parks, regional development area, urban recovery zone). The paper deals with a taxonomy of zones based on specialisation, and planning and management features.

M.I. Luger has extensively described differences based on the objectives of industrial park strategies, physical placement, typical activities, cooperation with universities, access to infrastructure, incentives, etc. Thus, Luger defines six main blocks of differences: objectives, size and actual location of parks, ownership and management, distinctive activities and occupiers, cooperation with universities, infrastructure, equipment, and services [4]. Given the global trends, it is very rational that the understanding of what a modern industrial park should be has changed. P. Formica writes about 4thgeneration industrial parks, based on four key aspects: brain exchange, circular economy in the context of research, many players involved and experimental laboratories [5].

Although there is no uniform industrial park model, it is possible to identify common objectives of these parks - providing support to business, involving different players, while also benefiting the region, the city, and the municipality. In addition to Formica's statement on the role of universities in industrial parks and the need for a strong scientific base, it is also worth mentioning of M.P. Feldman's and S. Breznitz's summary on the role of universities in industrial parks, which cover three important blocks of development function [6]:

1. knowledge transfer - commercialisation and transfer of technology, support to business;

2. policy development - research on economic trends, recommendations and forecasts, labour development;

3. economic development initiatives - building partnerships, development of the community, real estate development.

In the era of Industry 4.0 and digital change, all organisations and businesses are facing a more dynamic, more virtual, educated, mobile, creative human capital market. In addition, the issue of talent shortages is becoming more pressing. The ability to raise, hold and attract the critically needed flow of talents is a challenge today faced by all organizations [7]. There is no exact and constant formula because the country's specificities are different, but the authors consider that the checklist proposed by the United Nations Economic and Social Commission of Asia and Pacific (UN ESCAP) provides insight into the main factors affecting industrial park activity. These factors are anchor companies, management team, strong scientific background, business culture and availability of funding [8]. Wide literature analysis allows to conclude that the main factors that have an impact on the successful development of industrial parks are the existence of an anchor company, political will, the role of municipality and university, fiscal incentives, past sectoral traditions, labour force factors and talent policies.

The research continuation includes analysis of several case studies - Oulu Smart City (Oulu, Finland), Sophia Antipolis (Valbonne, France), Shannon Free Zone (Shannon, Ireland). In all cases there was a strong presence of early located anchor company - Nokia Mobile Phones for Oulu, Amadeus, IBM, Texas Instruments, France Telecom for Sophia Antipolis, and Zimmer, DeBeers, Intel for Shannon Free Zone. In all cases, political will has played an important role, often being charismatic leaders and 
with a broad range of contacts. Ilmo Paanen, Major of the Oulu, initiated creation of smart city, in case of Sophia Antipolis Pierre Lafitte had extensive network of contacts, strong will and ability to attract cooperation partners and develop the project in green forest area, while in Shannon Brendan O'Regan, innovator and businessman, developed and presented a proposal on the establishment of SEZ at the top of economic decline. In each of the industrial parks, priority development sectors have historically emerged, which also identified park development directions - the ICT sector in Oulu, Sophia Antipolis it was interdisciplinary merger of tourism with ICT sector, but in Shannon it was aviation services. Fiscal incentives in industrial parks differed, but included special tax policies, especially regarding human capital and investors, and start-up incubators were created in all industrial parks. The solid role of universities should be highlighted in the context of all industrial parks. The University of Oulu is considered as the basic source of engineering talent for an industrial park where universities and laboratories work closely together. The University of Sophia Antipolis was the intersection of knowledge generation between companies and organisations, particularly by highlighting technology and engineering. On the other hand, Shannon Free Zone introduced the first innovation centres in Europe to attract investors, University of Limerick was founded over time, talent policies were developed in all industrial parks. Oulu, for example, created special education programmes for talent creation, also attracted talented teaching staff, created the necessary infrastructure. Sophia Antipolis had flexible immigration policy, provided housing for employees and students, while Shannon particularly focused on investments in the training and retraining of employees. Similarly, the impact of the municipality has been crucial for the development of all parks. The Oulu municipality developed an industrial development policy, adapting the existing development policy to the needs of rapidly expanding lone star (Nokia Mobile Phones) at the centre of the industrial park, as well as establishing cluster development strategies. In the case of Shannon, the municipality also actively engaged in the attraction of international companies. It should be acknowledged that the development of each park mentioned above is worth further research, but the common features and key moments were identified.

The analysis of the Liepaja SEZ case study was executed by three expert interviews. Key issue of the interview: how to ensure faster economic growth in Liepaja by achieving a level of living in a city above the average in the European Union, exploiting the specialisation of the LSEZ and Liepaja?

Uldis Pilens, CEO of the JSC UPB and the first head of LSEZ, stressed the skilled human capital and qualitative local education system as a main critical success factor. Educated people are conscientious people. Mr. Pilens highlights weak housing supply for city's specialists, emphasizes the importance of investment in development - development is a jumping-off, such is the nature of investment. He recommends that sectoral training centres be set up not in the universities themselves but in the "grands", leading and developed industries, in cooperation and forcing the universities to become entrepreneurial and "change".

J. Oslejs, CEO of Primex with 40 mill. EUR sales, recommended to assess objectively the sectors that create the greatest added value, align with the traditions and capabilities of Liepaja, specialise, and create competitive advantages thus creating rapidly growing and companies of size (from 50 to 100 mill. EUR annual sales according to Alisdair Reid Scotland's smart specialised policy for regions [9]. In his view, Liepaja's challenges and capabilities relate to technological solutions and niche products, such as virtual and expanded reality. Opportunities are also determined by the presence and accessibility of a skilled workforce, linked to mobility. The focus to FDI as a source of new techniques, skills, talent, and innovation may grow to strong local university in a long run.

J. Hermanis, financial expert at Employers Union, suggests promoting innovation culture and share of innovative growth firms. Mr. Hermanis points out that continuous emigration of labour to western countries where low skill jobs are paid as minimum triple times higher as in Liepaja, reflects the challenge for the city. Mr Hermanis highlighted that promotion of much higher wage jobs in manufacturing industry, construction, transport, and logistics may change the situation. This includes companies with high export share and high added value. For now, only $1 \%$ of Liepaja companies can provide monthly wage above EU average. He stresses that large service companies formed because of privatisation or still publicly owned (like LMT, TET, Latvenergo, VASES, LTVRC, Latvijas GAS, Riga Water, municipal heating companies etc.) should much more invest in local supply of innovative and frontier technologies. On this basis, Liepaja as an innovation testbed for the whole country, a model for the future economic development should also be developed. 


\section{Global trends}

The foresight studies for Finland recommend promoting automation based on a mini and micro robotics, artificial intelligence and high-performance computing as wide interdisciplinary application, promotion of high value-added bioeconomy and ICT based social entrepreneurship. The digital age, industry 4.0 revolution, aging society, and gradual replacement of Nokia's collapse by fresh bioeconomy manufacturing sites, green energy and exploitation of forest resources are recipes for Finnish economy.

Several literature sources outline that one of major critical success factor for regional and national economic development is technology absorption readiness [10-12]. The readiness to select and adopt incremental innovations, born in external markets and provided to domestic firms as a part of new knowledge transfer is one of the most efficient ways of the public support to local enterprises. Limits set by the pandemic period make this factor even more valuable. Aggregated conclusions we can visualize in Fig. 1.

Technological frontier providing opportunities for incremental innovations

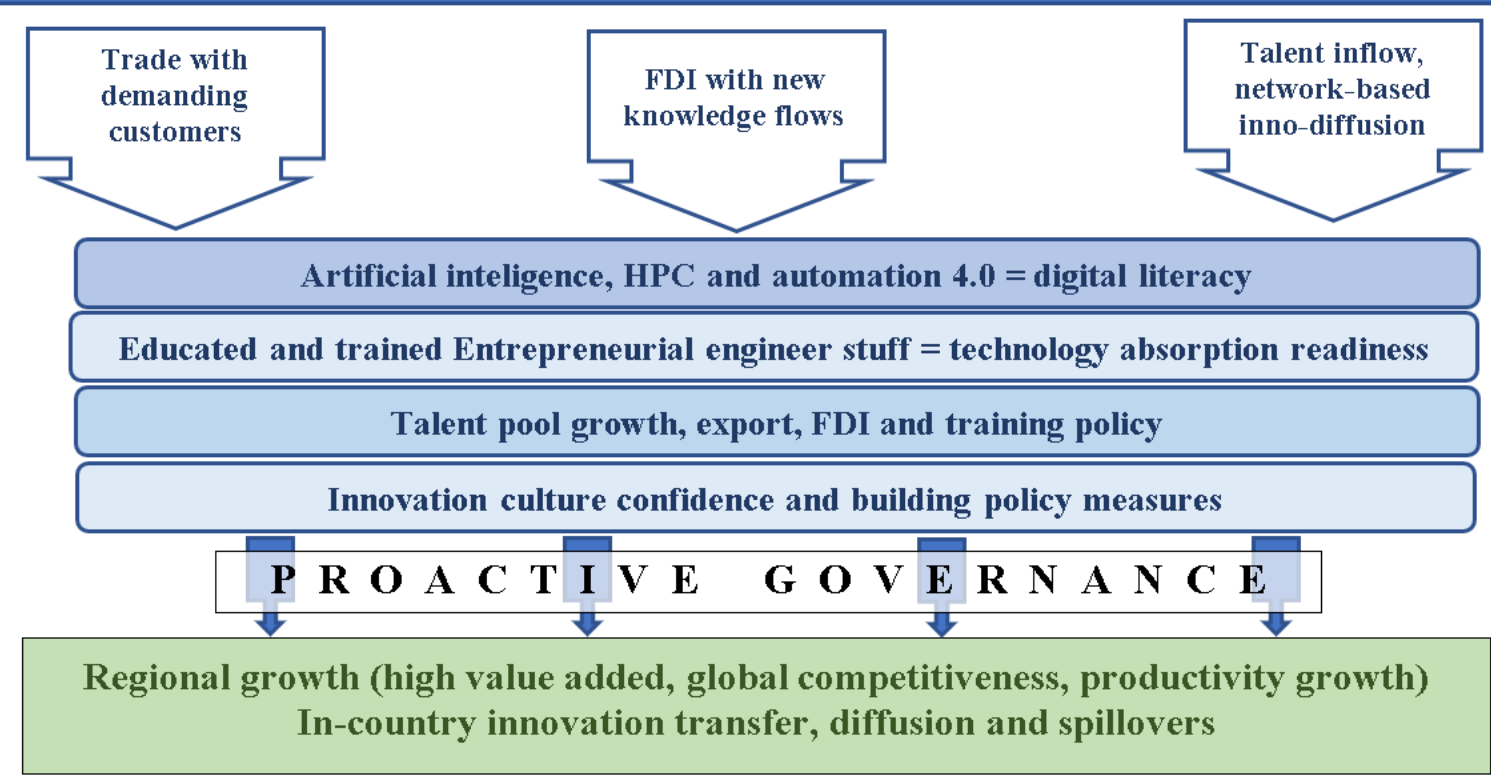

Fig. 1. Technological frontier providing opportunities for incremental innovations. Author's modification of World Bank scheme [10]

Global FDI investment volume decreased by $60 \%$ because of the global financial crisis in 20162018, UNCTAD forecasts that FDI global volume will fall by another $40 \%$ because of the Covid pandemic by the end of 2021. This will be caused by various restrictions accompanying pandemics lockdown - limited movement of people and goods, import and export restrictions, followed by a small movement of capital [13].

An analysis by the authors shows that, overall, it is important to look at three major global technological developments that may affect the performance of ports of Liepaja and SEZ (see Table 1).

Digitalization not only affects the length, geographic distribution, and governance of the value chain, but also reshapes its value-added configuration. Digital technologies, such as the AI, HPC, IoT and Big Data, emphasize intelligence downstream, shifting value added towards the lower supplier tiers, and importance of intangibles in the value chain, particularly $R \& D$ and innovation on the upstream side concentrating in Multinational Corporations (MNCs) [14]. Reshoring is by far the most relevant effect of automation on international production and global value chains. But automation will have an impact on the length and governance of GVCs as well [15]. Advanced industrial robotics and collaborative robots become cheaper and make it possible to perform complex sequences of tasks, generally leading to rebundling of steps. In terms of governance, the lower tier suppliers can keep their role only increasing reaction time, competence, and financial wealth, as robots still require significant capital investment [16]. 
3D printing is potentially one of the most revolutionizing technologies for global value chains [1718]. The main disruptive power of 3D printing is its technical and economic feasibility, which will shorten GVCs for all industries to some degree. Such sector as footwear, may undergo dramatic changes. Overall 3D printing points to a configuration of international production are characterized by smallscale, localized production. This takes place through the simultaneous effects of rebundling and offshoring.

Table 1

New global technology trends [13]

\begin{tabular}{|c|c|c|}
\hline Trend & Description & Proposals for Liepaja \\
\hline Digitalization & $\begin{array}{l}\text { Introduction of modular supply } \\
\text { chains, lowering costs, niches } \\
\text { for new partners } \\
\text { - Transfer to more dispersed } \\
\text { supply chains } \\
\text { - Increasing importance of } \\
\text { customer data and product } \\
\text { customisation shifts value to the } \\
\text { end of the chain }\end{array}$ & $\begin{array}{l}\text { - Introduction of the } \\
\text { Manufacturing Advisory } \\
\text { Service program } \\
\text { - Build focused cluster } \\
\text { programs, thereby promoting } \\
\text { digital start-up development } \\
\text { - Introduce Smart city concept } \\
\text { in Liepaja }\end{array}$ \\
\hline $\begin{array}{l}\text { Artificial } \\
\text { Intelligence (AI) } \\
\text { and advanced } \\
\text { robotics }\end{array}$ & $\begin{array}{l}\text { The importance of increasing } \\
\text { artificial intelligence, } \\
\text { mechanical and collaborative } \\
\text { robotics, digital innovation, } \\
\text { especially predictive modelling }\end{array}$ & $\begin{array}{l}\text { - "Smart port" with value- } \\
\text { added logistics with } \\
\text { integrated artificial } \\
\text { intelligence } \\
\text { - Exploit opportunities driven } \\
\text { by reshoring and rebundling } \\
\text { of value chains }\end{array}$ \\
\hline $\begin{array}{l}\text { Additive } \\
\text { manufacturing (3D } \\
\text { printing) }\end{array}$ & $\begin{array}{l}\text { End-to-end indivisible } \\
\text { production reduces modularity } \\
\text { - Increasing role for multiple } \\
\text { locations, for geographic } \\
\text { proximity to market and product } \\
\text { customization } \\
\text { - Increasing IP role in design }\end{array}$ & $\begin{array}{l}\text { - Smart construction and } \\
\text { modern construction } \\
\text { materials }\end{array}$ \\
\hline
\end{tabular}

If we conclude that R\&D concentration in the US or at least in some of the main EU R\&D cities will increase [13], the University of Liepaja would aim to develop strategic cooperation with a highquality US engineering university and attract anchor investors in a couple of niche industries, while increasing the technology absorption readiness in these three priority technology niches.

\section{Results and discussion}

All the advantages of the Baltic SEZ and industrial parks are very similar and real estate rent based. Too little attitude is devoted to frontier high-tech innovative leader attraction, talent growth and university role as a new knowledge source. Long-lasting isolated focus to social sciences and weak backward linkages has resulted in dramatic decline of the Liepaja University, also proved by international rankings.

Liepaja (as Latvia in whole) has low technological intensity, low productivity, low innovation capacity, low export levels, insufficient qualifications, poor management, and technology absorption capacity. For example, technological intensity in companies does not lead to thinking about the potential for rapid growth: 53, $2 \%$ of manufacturing companies in Liepaja are low-tech companies, in a small number of companies' technology intensity is medium high or high $-6,7 \%$ and $1,5 \%$ respectively (see Fig. 2). 


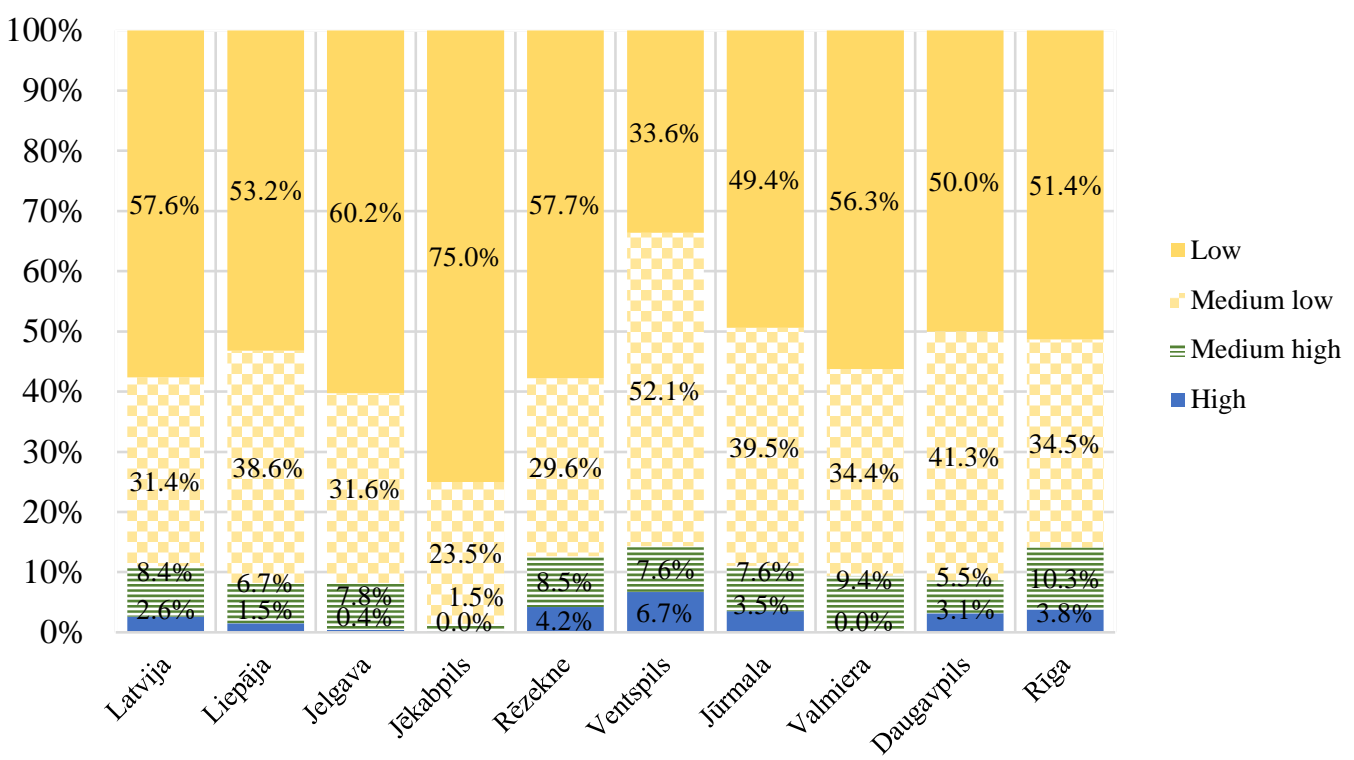

Fig. 2. Manufacturing companies in Latvia's cities by technological intensity [19]

Nearly half of the employees in Liepaja are employed in low-tech companies, which are slightly above the average of Latvia, while Liepaja lags Jelgava, Daugavpils and Ventspils (see Fig. 3).

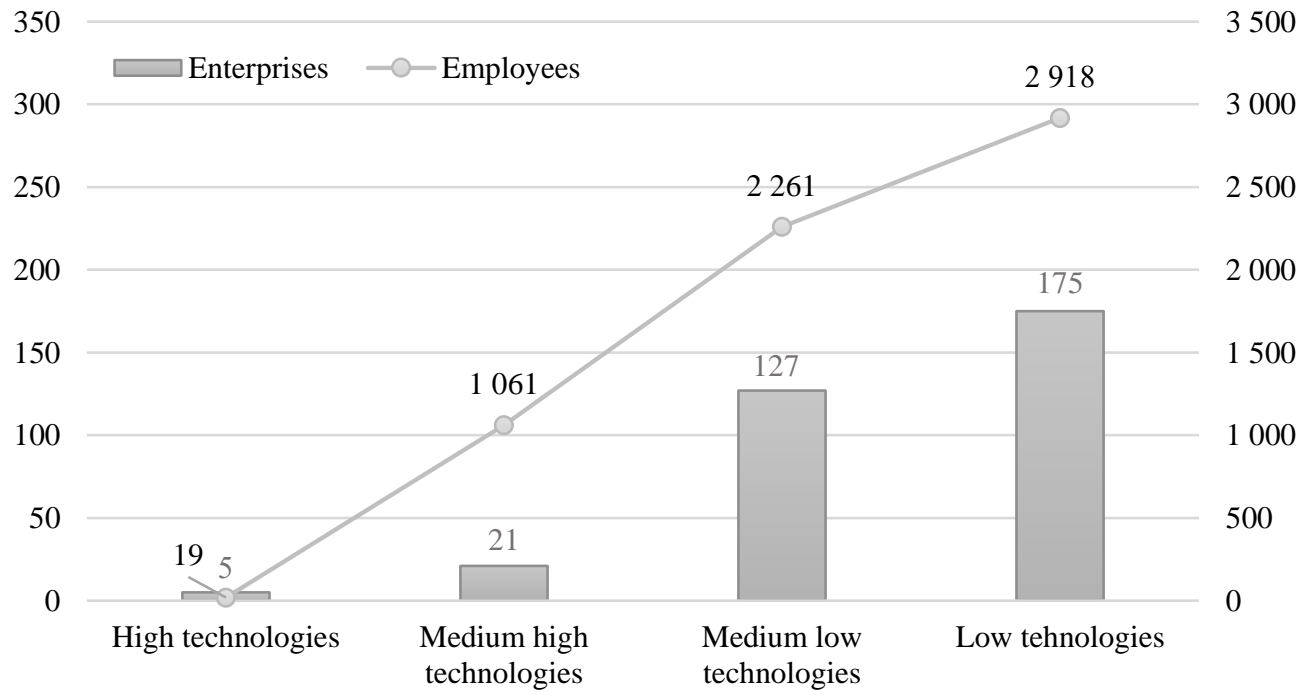

Fig. 3. Technological intensity of manufacturing companies and employees in Liepaja in 2019 [19]

Therefore, this fact raises a reflection on the significant shortcomings in the existing education system or in the social-economic environment that promotes it.

From the point of view of the development of a "smart economy", the performance of the University of Liepaja at international level is relatively low. Consequently, to increase the number of high valueadded company jobs in Liepaja and to ensure an increase in average gross wages up to the level of Riga and other Northern European metropolitan areas, city's HEI should pass significant change.

It can be concluded that SEZ governance activities are the management of SEZ with clearly defined priorities, political will and initiative, the availability of a talented highly skilled and motivated workforce, meaningful use of fiscal incentives and cooperation with the university. The authors provide the results of Liepaja case analysis, including performance of the key factors.

LSEZ should promote the attraction of anchoring companies with substantial FDI to bring new innovations to the Liepaja clusters, attract prospective businesses - fast-growth companies, lifestyle businesses and hidden champions (see Fig. 4). 


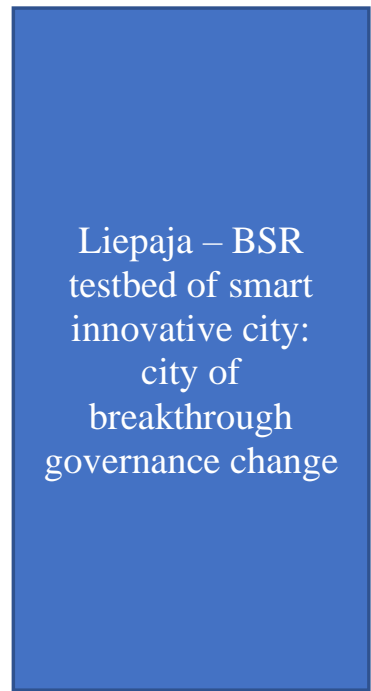

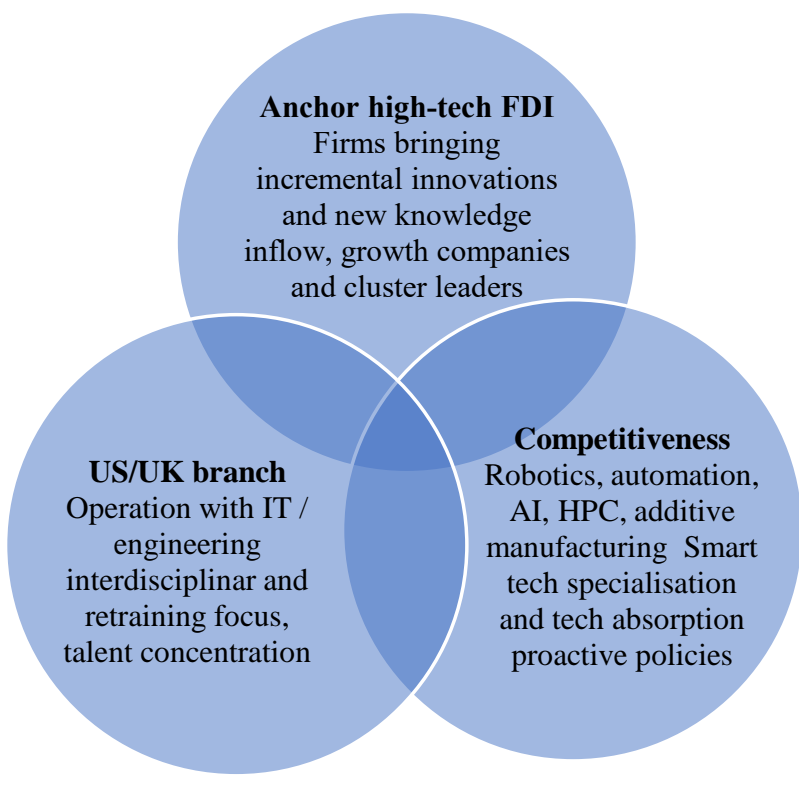

Fig. 4. Vision of development of Liepaja city

\section{Conclusions}

1. The economic situation of Liepaja is characterised by low wages, low innovation capacity and technology absorption capacity, low productivity, and low-skilled labour. More than half or 53\% of companies in Liepaja are low-tech companies, in a small number of companies technology intensity is medium-high or high $-6 \%$ and $2 \%$, respectively.

2. For several decades, the SEZ has proven itself to be an effective instrument for promoting regional development, but in the face of today's challenges, the SEZ should be able to develop local innovation eco-system, based on talent, external incremental technology absorption and caption of new value chain changes based on new role of lower tier suppliers and GVC rebundling.

3. Attraction of strong anglo-saxon technical university in Liepaja and focus to manufacturing cluster needs should become a new strategic goal of city SEZ and HEI itself.

4. Liepaja's SEZ should increase its governance capacity to attract foreign anchor companies, future high tech, and high value-added cluster leaders. The human capital and talent growth, as well as promotion of innovation culture should become a backbone of the new SEZ strategy.

5. Smart city concept should be in focus of further research ordered by the city council. Internationalisation should be introduced in all levels of public and private sector and supported by improvement of Liepaja's business environment.

\section{References}

[1] Watkins A., Agapitova N. Creating a 21st Century National Innovation System for a 21st Century Latvian Economy. Policy Research Working Paper; No.3457. World Bank, Washington, D.C., 2004. [online] [15.04.2021]. Available at: https://openknowledge.worldbank.org/handle/10986/14186.

[2] European Innovation Scoreboard 2020. [online] [17.04.2021]. Available at: https://ec.europa.eu/docsroom/documents/42981.

[3] Lofsten H., Lindelof P. Science Parks and the growth of new technology-based firms - academic industry links, innovation and markets. Research Policy, vol 6, 2002, pp. 859-876.

[4] Luger M. Science and technology parks at the Millenium: Concept, history and metrics. A background paper for planners of the Ames S\&T park. National Research Council, 2001, pp.95111.

[5] Formica P. Science and technology parks (STP): The Evolution. International Organisation for Knowledge Economy and Enterprise Development 2009. [online] [15.02.2021]. Available at: http://www.iked.org/pdf/4TH\%20Generation\%20STPs.pdf. 
[6] Breznitz S., Feldman M. The engaged university. The Journal of Technology Transfer, vol 37 (2), 2012, pp. 139-157.

[7] Tarique I., Schuler R. Global talent management: literature review, integrative framework, and suggestions for further research. Journal of World Business, vol. 45, 2010, pp. 122-133.

[8] The United Nations Economic and Social Commission for Asia and the Pacific (ESCAP). Establishing Science and Technology Parks: A Reference Guidebook for Policymakers in Asia and the Pacific 2019. [online] [15.02.2021]. Available at: https://www.unescap.org/sites/default/files/Guidebook_Final_0.pdf.

[9] Reid A. A smart, sustainable nation? A review of Scottish research and innovation policy in the context of the smart specialisation agenda. Technopolis technical report, 2012, $68 \mathrm{p}$.

[10] Goldberg I., Branstetter L., Goddard J.G., Kuriakose S. Globalisation and technology absorption in Europe and Central Asia. The role of trade, FDI, and Cross-border knowledge flows. WB Working paper No.150, 149 p.

[11] Tidd J. Managing Knowledge, Absorptive Capacity and Innovation. Series of technology management, vol. 37, 2021. [online] [13.04.2021]. Available at:

https://www.researchgate.net/publication/349590126_Managing_Knowledge_Absorptive_Capacit y_and_Innovation.

[12] Runiewicz-Wardyn M. The Role of Knowledge Absorption and Innovation Capability in the Technological Change and Economic Growth of EU Regions. International Journal of Management and Economics, 2014.

[13] UNCTAD. World Investment Report 2020. International production beyond pandemic. [online] [14.04.2021]. Available at: https://unctad.org/system/files/official-document/wir2020_en.pdf.

[14] Garay-Rondero C., Flores J.S., Smith N., Caballero O., Aldrette-Malacara A. Digital supply chain model in Industry 4.0. Journal of Manufacturing Technology Management, Vol. 31, No. 5, 2019 pp. 887-933.

[15] Artuc E., Chaudhuri S., and McLaren J. Trade shocks and labor adjustment: A structural empirical approach. The American Economic Review, vol.100, no. 3, 2010, pp. 1008 - 45.

[16] Narula, R. Enforcing higher labor standards within developing country value chains: Consequences for MNEs and informal actors in a dual economy. Journal of International Business Studies, vol. 50, 2019, pp. 1622-1635.

[17] Laplume A., Petersen B., Joshua P. Global value chains from a 3D printing perspective. Journal of International Business Studies, vol. 47, no.5, 2016, pp. 595 - 609.

[18] Buonafede F., Felice G., Lamperti F., Piscitello, L. Additive manufacturing and global value chains: an empirical investigation at the country level. Progress in International Business Research, vol. 13, 2018, pp. 295-323.

[19] Centrālā Statistikas pārvalde (CSP). Apstrādes rūpniecības uzṇēmumu tehnoloǵiskā intensitāte, 2019. (Central Statistical Bureau (CSB). Technological intensity of manufacturing companies 2019, year 2019). 